dr. sc. Katerina Fotova Čiković

Sveučilište Sjever, Koprivnica, Republika Hrvatska

kcikovic@unin.hr

\title{
UTJECAJ ČIMBENIKA POZNATOST MARKE, PERCEPCIJA KVALITETE I AKTIVNOSTI DIGITALNOG MARKETINGA NA TRŽIŠNU VRIJEDNOST MARKE NA PRIMJERU HRVATSKOG PODUZEĆA KATEME
}

Primljen: 7. siječnja 2021.

Prihvaćen: 30 . lipnja 2021.

https://doi.org/10.46458/27121097.2021.27.25

\section{Prethodno priopćenje}

\section{Sažetak}

U današnjem konkurentskom okruženju, brandiranje je važan čimbenik konkurentnosti koji diferencira slične proizvode i usluge u svijesti potrošača i čini ih poželjnijima za potrošače. Brand (ili marka) odražava autentičnost, vrijednost i predanost proizvodima i uslugama (Bilgin, 2018). Tržišna vrijednost marke ključna je varijabla o kojoj ovisi tvrtkin uspjeh, rast te percepciju potrošača.

Vrijednost ovog rada je u činjenici da je istraživanje tržišne vrijednosti marke u industriji antikviteta, starina $i$ stilskog namještaja na svjetskoj razini nedovoljno zastupljeno u istraživanjima te su radovi koji su se bavili ovom problematikom rijetki. Ovo je empirijsko istraživanje imalo za cilj utvrditi utjecaj čimbenika poznatosti marke, percepciju kvalitete, aktivnosti digitalnog marketinga na tržišnu vrijednost marke, te dodatno analizirati percepciju marke u industriji antikviteta, starina i stilskog namještaja na slučaju poduzeća iz sjeverne Hrvatske. Statistički testovi, uključujući test pouzdanosti, validnosti, analize korelacije te regresijske analize, korišteni su tijekom ovog istraživanja.

Rezultati istraživanja upućuju na to da poznatost marke i aktivnosti digitalnog marketinga pozitivno i značajno utječu na tržišnu vrijednost marke, dok percepcija kvalitete, imajući $u$ vidu da se ovdje radi o trgovini starinama, tj. starim i rabljenim predmetima, nije statistički značajna u objašnjavanju zavisne varijable. 
Znanstveni doprinos ovog istraživanja ogleda se u činjenici da se ovaj rad može koristiti kao osnova za daljnja istraživanja u ovoj relativno slabo istraženoj industriji te se zaključci i model mogu primijeniti i kod drugih industrija, naročito kako bi se povećala konkurentnost malih i srednjih poduzeća. Rad sugerira da bi marketinški stručnjaci trebali pažljivo razmotriti dimenzije tržišne vrijednosti marke prilikom osmišljavanja svojih strategija marke.

Ključne riječi: tržišna vrijednost marke, digitalni marketing, poznatost marke, percepcija kvalitete

JEL: M31

\section{UVOD}

U posljednjem su desetljeću informatička tehnologija, digitalizacija te digitalni marketing značajno promijenili način poslovanja i marketinga, kao i način na koji tvrtke pristupaju svojim kupcima (Fotova Čiković, 2020). Prijelaz na gospodarstvo temeljeno na znanju te ogroman razvoj informacijskih i komunikacijskih tehnologija (IKT) potiču tvrtke da pronađu inovativne pristupe marketingu i poslovanju (Brogi et al., 2013). Pažnja potrošača, u današnjoj ekonomiji obilja, postaje jedini nedostatak. Istodobno, u svijetu preopterećenosti informacijama postaje sve zahtjevnije istaknuti se i doći do faze da potrošač prepoznaje te preferira određenu marku (Širola \& Gallopeni, 2020).

Marka je jedno od najvažnijih nematerijalnih sredstava u današnjim poduzećima i u mnogim slučajevima poduzeće se uglavnom cijeni na temelju njegove marke (Azad \& Safaei, 2012). Prema Keller (2003a), različite vrste informacije mogu postati povezane s markom, te postaju ključne dimenzije marke uključujući: poznatost marke, atribute, benefite i koristi, slike, misli, osjećaje, stavove i iskustva. Sve se definicije marke svode na ime - naziv, simbol, oznaku koja identificira cijelo poduzeće ili skupinu njegovih proizvoda, usluga (Vranešić \& Marušić, 2003). Prema Američkom udruženju za marketing (AMA), marka je 'Ime, pojam, znak, simbol ili dizajn ili njihova kombinacija namijenjena identificiranju robe i usluge jednog prodavača ili grupe prodavača i razlikovati ih od konkurencije‘. Po tome, smatralo bi se da se svaki put dok neki dizajner izradi novi logo ili se otvori nova tvrtka, istovremeno se izgradi i marka. Definiranje marke treba se dopuniti i u smislu stvaranja određene količine svijesti, ugleda, istaknutosti i diferencijacija na tržištu (Keller, 2003b). Marke predstavljaju osnovu na kojoj se organizacije postavljaju u konkurentno okruženje. One služe kao vitalni element razlikovanja 
$\mathrm{u}$ onome što bilo koja organizacija nudi u odnosu na svoje konkurente (Balakrishnan et al., 2009).

Tržišna vrijednost marke (brand equity) je kategorija koja se sve više analizira i istražuje te je upravljanje markama u brzorastućoj industriji potrošačkih proizvoda sve zahtjevnije. Stoga je tržišna vrijednost marke ključna i središnja varijabla, i tvrtke ulažu sve veće napore kako bi ih priopćili svojim ciljanim potrošačima (Asif et al., 2015).

Tržište luksuznih dobara i naročito tržište umjetnina i antikviteta postiglo je zrelost, zajedno s postupnim širenjem opsega svog tržišta i brzog rasta broja kupaca. Luksuzno tržište industrija je s visokom dodanom vrijednosti koja se temelji na imovini visoke vrijednosti tržišne marke. Smanjenje prodaje uslijed globalne ekonomske krize (2007. - 2009.) te općeniti pad potražnje i rast konkurencije na tržištu potaknulo je tvrtke na promjenu poslovanja. Sada više ne mogu ovisiti samo o svom simbolu marke, nego se moraju usredotočiti na kvalitetu, estetsku vrijednost i povjerljive odnose s kupcima kako bi uspjeli. Ključni element luksuzne industrije postaje pružanje vrijednosti kupcima i biti im dostupan na svaki mogući način (Kim \& Ko, 2012). Industrija antikviteta, starina i stilskog namještaja, pak, industrija je čija je pozicija već desetljećima ugrožena. Neki od problema s kojima se suočava uključuju promjenu ekonomskih okolnosti, promjene u načinu života potrošača te jednostavna činjenica smanjene dostupnosti određenih predmeta (Art and antiques trade, 1998). Analizirana tvrtka iz Koprivnice Katema, obrt za trgovinu, marketing i usluge, registrirana je u lipnju 2017. godine, te je jedna od malo tvrtka u Republici Hrvatskoj koje se bave trgovinom starina, umjetnina, antikviteta te stilskim namještajem. Ovo će istraživanje dati zanimljive uvide o tome kako poznatost marke, percepcija kvalitete i aktivnosti digitalnog marketinga (te digitalizacija poslovanja) utječu na tržišnu vrijednost marke u jednoj konzervativnoj industriji te vrijede li u ovoj industriji ista pravila kao i kod drugih.

Da je malo i srednje poduzetništvo važno, govori činjenica da strukturu hrvatskog gospodarstva čine, kao i u većini zemalja, sektor malih i srednjih poduzeća s daleko najvećim udjelom u broju poduzeća $(99,7 \%$ u 2018.). Sektor mikro, malog i srednjeg poduzetništva u 2018. godini činio je $58 \%$ ukupnog prihoda generirane na razini Hrvatske. U ukupnom izvozu hrvatskih poduzeća u 2018. godini sektor malog i srednjeg poduzetništva sudjeluje s udjelom od 53 \% (Alpeza et al., 2018). Stoga se da zaključiti da je malo i srednje poduzetništvo motor rasta te se zbog toga potiče registracija novih poduzeća od strane države, županija i gradova u Republici Hrvatskoj. Lokalne vlasti također prepoznaju vrijednost novih poduzeća za razvoj lokalne zajednice te nude razne programe poticanja poduzetništva. Grad Koprivnica, osim toga što nudi poduzetničke zone s olakšicama za investitore, ne 
naplaćuje prirez, za gradnju poslovnog objekta umanjuje komunalni doprinos od $25 \%$ do $100 \%$, nudi posebne olakšice za osobe s invaliditetom, zatim mogućnost snižavanja prodajne cijene parcele do $95 \%$, te pravo građenja po godišnjoj naknadi $1 \mathrm{kn} / \mathrm{m} 2$ za prvih 48 mjeseci, nudi i poduzetničke inkubatore koji mogu poslužiti kako oslonac start-up-ovima te novim poduzetnicima (Grad Koprivnica, 2020).

Glavni je cilj ovog istraživanja steći dublje razumijevanje o tome kako te u kojoj mjeri poznatost marke, percepcija kvalitete te aktivnosti digitalnog marketinga utječu na tržišnu vrijednost marke na uzorku potencijalnih i postojećih kupaca jednog malog poduzeća.

Ostatak rada organiziran je na sljedeći način. U odjeljku 2 bit će predstavljen pregled literature i rezultati dosadašnjih istraživanja, odjeljak 3 opisuje korištenu metodologiju, podatke i teorijski okvir, nakon čega slijedi prezentacija rezultata i analiza u odjeljku 4. Konačno, rad je završen raspravom, ograničenjima studije i opisom budućeg rada u odjeljku 5 .

\section{PREGLED REZULTATA DOSADAŠNJIH ISTRAŽIVANJA}

\subsection{Poznatost marke (Brand Awareness)}

Poznatost marke važna je za dobre tržišne rezultate tvrtke i naročito je ključna za nove i male tvrtke te se najčešće definira kao sposobnost identificirati, prepoznati ili sjetiti se neke marke u određenoj kategoriji (Aaker, 1991; Keller, 1993). Poznatost marke prvi je korak prema formiranju tržišne vrijednosti marke te je njezina ključna determinanta (Rockute et al., 2018; Keller, 2003a; Aaker, 1996). $\mathrm{Na}$ samom početku poslovanja, bitna je svjesnost za ime tvrtke kao prvi korak prema građenju tržišne vrijednosti marke, koja je fokusirana na potrošača i njegov izbor (Keller, 2013).

Sposobnost potencijalnog kupca prepoznati i sjetiti se marke kao dijela određene kategorija proizvoda predstavlja poznatost marke. Ona je podijeljena u četiri faze, i to: nesvjesnost o marki, prepoznavanje marke, sjećanje na marku i vrh uma. Najniža razina prepoznatljivosti marke je prepoznavanje marke ili razina potpomognuto sjećanje. Nakon toga je razina sjećanje na marku bez pomoći jer potrošačima ne treba pomoć da se sjete marke. Pomoć u potpomognutom prepoznavanju marke može biti poster, video, reklame, natpisi ili kanali društvenih mreža. Zadnja razina poznatosti marke, koja je prvi put predstavljena u prepoznavanju marke bez pomoći, naziva se vrhom uma (svjesni vrh uma). Vrh uma 
najviša je svijest o marki koja je na vrh drugih različitih marki koje postoje u svijesti potrošača (Tritama \& Tarigan, 2016).

\subsection{Percepcija kvalitete (Perceived quality)}

Aaker (1991) predlaže četiri dimenzije tržišne vrijednosti marke: poznatost marke, lojalnost marki, asocijacije na marku te percepcija kvalitete. Percepcija kvalitete definira se kao kupčeva prosudba o cjelokupnoj izvrsnosti ili superiornosti proizvoda u odnosu na alternativne konkurentne marke. Percepcija kvalitete povezana je s cjenovnim premijama, elastičnošću cijena, upotrebom marke i povratkom robe. Nadalje, visoko je povezana i s drugim ključnim mjerama tržišne vrijednosti marke (Aaker, 1996).

Zeithaml (1988) također definira kvalitetu kao superiornost ili izvrsnost. Nadalje, percepcija kvalitete može se definirati kao prosudba potrošača o ukupnoj superiornosti ili izvrsnosti proizvoda. Stoga, tvrtke zaista moraju povećati stvarnu kvalitetu svojih marki, a zatim tu kvalitetu priopćiti svojim marketinškim akcijama kako bi pozitivno utjecale na percepciju kvalitete.

Prema equity teoriji, percepcija kvalitete predstavlja neto razliku između onoga što potrošači dobivaju i onoga što žrtvuju (u obliku novca, potrošnje vremena ili pretrpljenog stresa) te je temelj za individualnu procjenu potrošača o tome što je fer ili korisno. Stoga, percepcija kvalitete može se definirati kao potrošačeva cjelokupna procjena rizika i nagrada povezanih s određenom robnom markom i njezinim proizvodima (Civelek \& Ertemel, 2019).

Iako je percepcija kvalitete česta varijabla u modelima za procjenu učinaka na tržišnu vrijednost marke, ipak, u nekim kontekstima možda nije ključni pokretač tržišne vrijednosti marke (Aaker, 1996).

\subsection{Aktivnosti digitalnog marketinga (Digital Marketing)}

Digitalni marketing pojavio se kao specijalnost tijekom posljednjeg desetljeća s podrijetlom utemeljenim u direktnom marketingu (Yuvaraj \& Indumathi, 2018). Digitalni marketing je vrsta marketinga koji se široko koristi za promociju proizvoda ili usluga i za dolazak do potrošača pomoću digitalnih kanala. Šri se i izvan internetskog marketinga, uključujući kanale koji ne zahtijevaju upotrebu interneta. Uključuje mobilne telefone (i SMS i MMS), marketing na društvenim mrežama, display oglašavanje, marketing putem pretraživača (SEM) i brojne različite vrste digitalnih medija (Krishnaprabha \& Tarunika, 2020). 
Svijet e-trgovine nedavno je napredovao zapanjujućom brzinom (Aslam et al., 2018). Prema Statista (2020), svjetska online maloprodaja narast će do 6542 milijardi američkih dolara (USD) u 2023. godini. Klasični marketinški pristupi u današnjem, sve više digitalnom, okruženju ne mogu nijednom gospodarskom subjektu donijeti tržišni uspjeh. Prateći promjene koje suvremeni marketing nameće, moraju se mijenjati i prilagođavati načini, ali i sredstva komuniciranja sa svim poslovnim agentima uključenim u procesu razmjene (Markić et al. 2018).

Tehnologije internetskog marketinga mogu pozitivno utjecati na odnos s kupcima, a istovremeno cijeli postupak učiniti učinkovitim i djelotvornim. Tvrtke mogu poboljšati odnose s kupcima i ciljne aktivnosti korištenjem interneta za sinkronizaciju postojećih komunikacijskih kanala (Eid \& El-Kassrawy, 2012). Tvrtke danas mogu koristiti interaktivne komunikacijske tehnologije i alate kao što su e-pošta, eCRM, društvene mreže i chatovi za personalizaciju i automatizaciju marketinških komunikacija (Harrigan et al., 2011). Kako digitalni kanali omogućuju dvosmjerne interakcije, tvrtke sve više teže stvaranju digitalnog odnosa s kupcima i s njima postaju partneri kako bi se postigla lojalnost i zagovaranje kupaca, kao i poslovna vrijednost (Krishnaprabha \& Tarunika, 2020).

Društvene su mreže kanal komunikacije s potencijalnim i postojećim kupcima, te su moćno sredstvo oblikovanja stavova, mišljenja i imidža o proizvodu ili usluzi. Izravna su komunikacija s kupcima ili korisnicima usluga neophodan alat za oblikovanje marke. Spoznati mišljenja kupaca ima ogromnu praktičnu vrijednost za poduzeće jer omogućuje proaktivno djelovanje i može usmjeriti operativne aktivnosti poduzeća kako bi svojstva i kvalitetu proizvoda ili usluge prilagodilo zahtjevima kupaca (Markić et al., 2018). Marketing preko društvenih mreža nudi brojne povoljnosti za tvrtke i omogućuje međusobnu komunikaciju marke i kupaca, bez ikakvih ograničenja u vremenu, mjestu i mediju tako da se staromodna jednosmjerna komunikacija mijenja u interaktivnu dvosmjernu izravnu komunikaciju (Kim \& Ko, 2012).

Digitalni marketing razlikuje se od tradicionalnih metoda marketinga; stoga zahtijeva posebnu pažnju i izgradnju strategije kako bi se povećala tržišna vrijednost marke (Krishnaprabha \& Tarunika, 2020). Tvrtke primjenjuju sve inovativnije poslovne i marketing strategije u svom poslovanju. Štoviše, tvrtke u sjevernoj Hrvatskoj smatraju inovativnost vrlo važnim faktorom rasta svoga poduzeća te su svjesne da je samo inovativnim poslovanjem i praćenjem svjetskih trendova moguće ostati konkurentan na tržištu, te su poduzetnici u sjevernoj Hrvatskoj počeli mijenjati način svoga poslovanja prema novim svjetskim standardima poslovanja (Primorac, 2020). Uvođenjem aktivnosti digitalnog marketinga te općenito digitalizacija poslovanja je uvelike pridonijela veću konkurentnost malih i srednjih poduzeća u Koprivnici te u Republici Hrvatskoj. 


\subsection{Tržišna vrijednost marke (Brand Equity)}

Koncept tržišne vrijednosti marke pojavio se ranih 1980-ih, te je tijekom 1990-ih privukao značajnu pozornost kako u znanstvenoj zajednici tako i u marketinškoj praksi, što je rezultiralo brojnim objavljenim člancima i knjigama na ovu temu (Rajh, 2005). Interes za tržišnom vrijednošću još je uvijek aktualan (Širola \& Gallopeni, 2020; Buil et al., 2008; Veloutsou \& Guzmán, 2017).

Iako su za proučavanje tržišne vrijednosti marke korištene razne perspektive, pristupi temeljeni na potrošačima analiziraju tržišnu vrijednost marke iz perspektive potrošača. Osnovna premisa modela tržišne marke temeljene na kupcu su da snaga marke leži u onome što kupci imaju u vidu u vezi marke, ono što su o njoj saznali, osjetili, vidjeli, čuli te kako je tekao rezultat njihovog iskustva tijekom vremena. Drugim riječima, snaga marke leži u misli potrošača ili kupaca i onoga što su iskusili i s vremenom naučili o marki (Keller, 2003b). Keller (1993) definira tržišnu vrijednost marke kao ukupnu snagu marke, koja odražava razinu poznatosti marke, imidž marke i lojalnost marki koju potrošači imaju za određenu marku.

Trenutno postoji veliki broj različitih definicija tržišne vrijednosti marke. Najčešce se definira kao zbir sredstava i obveze koje su povezane s nekim brandom ili markom, njezinim imenom, simbolom, logom, i koji se može zbrojiti ili oduzeti od ukupne vrijednosti dobivene kupljenim proizvodom ili uslugom (Širola i Gallopeni, 2020). Prema Aaker (1991), sredstva i obveze uključeni u tržišnu vrijednost marke mogu biti grupirani u 4 skupine: poznatost marke, lojalnost marki, percepciju kvalitete jedne marke te asocijacije na marku. Tržišna vrijednost marke je dodana vrijednost koju marka pruža proizvodu ili usluzi u usporedbi s vrijednošću sličnom nebrandiranom proizvodu ili usluzi (Veloutsou \& Guzmán, 2017).

Stvaranje tržišne vrijednosti marke, tj. izgradnja jake marke uspješna je strategija za razlikovanje proizvoda od konkurentskih marki (Aaker, 1991). Tržišna vrijednost marke osigurava održive konkurentske prednosti jer stvara značajne konkurentske barijere. Ona se razvija kroz poboljšanu percepciju kvalitete, lojalnost marki i poznatost i asocijacije na marku, što ne može biti niti izgrađeno niti uništeno u kratkom roku, ali se može stvoriti samo dugoročno kroz pažljivo osmišljena marketinška ulaganja. Dakle, tržišna vrijednost marke trajan je i održiv koncept, a proizvod s velikom tržišnom vrijednošću dragocjen je za tvrtku (Yoo, Donthu i Lee, 2000).

Tržišna vrijednost marke važna je jer posjedovanje dobro pozicionirane marke znači da je marka prepoznatljiva i poželjna među potrošačima (Aaker, 1996). 
Zanimljivo je što postoje prednosti tržišne vrijednosti marke i za potrošače, a to su: smanjenja nesigurnosti tijekom postupka kupnje, pojednostavljenja izbora, uštede vremena, truda i gnjavaže prilikom odabira odgovarajuće marke, poboljšanja imidža, samopouzdanja i samopoštovanja (Širola \& Gallopeni, 2020).

Istraživači sve više prepoznaju da je tržišna vrijednost marke kompleksna, višestrana i nelinearna konstrukcija, čije mjerenje zahtijeva sofisticirane metodologije i sustave tržišne vrijednosti marke koji, između ostalog, uzimaju u obzir karakteristike i pozicioniranje marke, specifični tržišni kontekst i segment kupaca (Veloutsou i Guzman, 2018).

Zbog toga su studije i istraživanja o tržišnoj vrijednosti marke mnogobrojne, te su one obuhvatile različite industrije i različita tržišta. Naime, Širola \& Galoppeni (2019) istraživali su utjecaj lojalnost marki, percepciju kvalitete i poznatosti marke u hrvatskoj industriji mobilnih operatera. Kim \& Lee (2018) fokusirali su se na tržišnu vrijednost marke turističkih destinacija. Seo \& Park (2018) promatrali su utjecaj marketinga socijalnih mreža na tržišnu vrijednost marke u zrakoplovnoj industriji. Tong \& Hawley (2009), analizirali su kreiranje tržišne vrijednosti marke u kineskoj tekstilnoj industriji, te im je glavni cilj bio prikazati utjecaj pojedinih marketinških aktivnosti na tržišnu vrijednost marke. Sasmita \& Mohd Suki (2015) su u svojoj studiji prikazali uvide mladih potrošača o tržišnoj vrijednosti marke. Naime, njihovo istraživanje uključilo je 200 mladih ispitanika (studenata) iz Malezije, dok je fokus istraživanja bila uzajamna veza i utjecaj poznatosti marke, lojalnost marke i imidž marke na tržišnu vrijednost marke. Jalilvand et al. (2011) koristili su Aakerov model u analizi automobilske industrije te su istražili utjecaj dimenzije tržišne vrijednosti marke na namjeru kupnje. Sean Hyun \& Kim (2011) analizirali su dimenzije tržišne vrijednosti marke kod 5 lanaca restorana u Koreji. Buil et al. (2008) razvili su multidimenzionalni model tržišne vrijednosti marke, koji se sastoji od poznatosti marke, percepcije kvalitete, asocijacije marke te lojalnost marki kod britanskog i španjolskog potrošača. Jung \& Sung (2008) koriste uzorak od 300 studenata kako bi ispitali učinke poznatost marke, percipiranu kvalitetu, asocijacije na marku te lojalnost marke na tržišnu vrijednost marke. Istraživanje Valette-Florencea, Guizani \& Merunka (2011) bavi se relativnim utjecajem osobnost marke i prodajne promocije na formiranju tržišnu vrijednost marke, dok Nam et al. (2011), pak, s druge strane istražuju kako tržišna vrijednost marke i lojalnost marki utječu na zadovoljstvo potrošača u hotelijerskoj i restoranskoj industriji.

Ipak, empirijske studije i istraživanja koja uključuju industriju antikviteta, starina i stilskog namještaja te industriju luksuznih dobara su rijetkost. Godey et al. (2016) su analizirali industriju luksuznih marki (Burberry, Dior, Gucci, Hermès, and Louis Vuitton), te im je glavni fokus bio brandiranje putem društvenih 
mreža. Štoviše, studija pokazuje veze između marketinških napora na društvenim mrežama i njihovih posljedica (sklonost robnoj marki, premija cijene i lojalnost). Studija mjeri marketinške napore na društvenim medijima kao holistički koncept koji uključuje pet aspekata (zabava, interakcija, trend, prilagođavanje i usmene preporuke).

Kako se tržišna vrijednost marke smatra jednim od najvažnijih organizacijskih resursa, ona je ključna kako za velike korporacije, tako i za mala i srednja poduzeća koja grade tržišnu vrijednost vlastite marke kako bi osigurali snagu svojih tvrtki. Veća tržišna vrijednost marke vodi prema povećanju prihoda, smanjenju troškova i povećanju dobiti. Dakle, istraživanje izvora tržišne vrijednosti marke postaje ključno (AbdGhani et al., 2021). Studija Dumitriu et al. (2019) predstavlja polazište za moderna mala i srednja poduzeća koja odluče slijediti put održivosti stvaranjem i jačanjem vlastite vrijednosti robne marke putem alata i tehnika digitalnog marketinga. Gorgani (2016) je istražio utjecaj medija društvenih mreža na tržišnu vrijednost marke u malim i srednjim poduzećima. Omar \& Ali (2010) su stavili fokus na upravljanje tržišne vrijednosti marke kod malih i srednjih poduzeća u hotelijerskoj industriji u Maleziji. Yoo, Donthu \& Lee (2000) su među prvima koji su istražili odnose između odabranih elemenata marketinškog miksa i stvaranja tržišne vrijednosti marke, te su u svom radu predložili konceptualni okvir u kojem su marketinški elementi povezani s dimenzijama tržišne vrijednosti marke (percipirana kvaliteta, lojalnost marki i poznatost marke u kombinaciji s sviješću o robnoj marki). Radovi i istraživanja u ovom su području mnogobrojni, ali oni često ne uključuju mala i srednja poduzeća, relativno novih maraka, te tržište antikviteta, starina i luksuznih dobara. Stoga, ovo je istraživanje originalno i doprinijet će ne samo svjetskoj literaturi, nego i marketinškim stručnjacima te vlasnicima malih i srednjih poduzeća u njihovom marketinškom pozicioniranju. Štoviše, ovo je prva empirijska studija o relativno novoj marki na tržištu antikviteta na području Republike Hrvatske.

Cilj ovog rada je steći dublje razumijevanje i nove uvide o tome kako, te u kojoj mjeri poznatost marke, percepcija kvalitete te aktivnosti digitalnog marketinga utječu na tržišnu vrijednost marke na primjeru relativno novog i malog poduzeća iz industrije antikviteta, starina i stilskog namještaja u Republici Hrvatskoj. Dodatni cilj je skrenuti pažnju na važnost istraživanja malih poduzeća i njihovog tržišnog pozicioniranja, te nadahnuti istraživače da poduzmu slična istraživanja kako bi akademska zajednica i marketing stručnjaci dobili nove uvide o tome što točno utječe na tržišnu vrijednost marke. 


\section{METODOLOGIJA ISTRAŽIVANJA I PODACI}

Ovaj rad koristio je svrsishodno uzorkovanje, također poznato kao prosudba, selektivno ili subjektivno uzorkovanje, kada se ciljni uzorak ne-vjerojatnosti odabire na temelju obilježja populacije i cilja studije (Venkatalakshmi, 2015; Crossman, 2020). U ovom je slučaju uzorak obično prilično malen te je glavni cilj ove tehnike uzorkovanja usredotočiti se na određene karakteristike populacije koje su zanimljive, što će najbolje omogućiti istraživaču da odgovori na njihova istraživačka pitanja. Uzorak koji se proučava nije reprezentativan za populaciju, ali za istraživače, to se ne smatra slabošću. Namjenski je uzorak jednostavno onaj u kojem se jedinice odabiru na temelju njihovih sličnih karakteristika, jer su takve osobine posebno zanimljive istraživaču. Budući da je cilj svrsishodnog uzorkovanja pristup kojim se mogu analizirati određene karakteristike, mišljenja ili stavova ciljne skupine, ta je tehnika uzorkovanja primijenjena u ovom istraživanju.

\subsection{Konceptualni model i hipoteze istraživanja}

Model korišten u ovom istraživanju prikazan je na slici 1. U svrhu ove studije, tržišna vrijednost marke (zavisna varijabla) sastoji se od poznatosti marke, percepcije kvalitete te aktivnosti digitalnog marketinga (nezavisne varijable). Za razliku od Širola \& Gallopeni (2020) koji su koristili trodimenzionalni pristup u njihovom istraživanju, spajajući varijable poznatost marke (brand awareness) i asocijacije marki (brand association) u jednu varijablu zbog njihove nerazdvojivosti, model u ovom istraživanju također je trodimenzionalan, ali uključuje tri nezavisne varijable te tržišnu vrijednost marke kao zavisnu varijablu. Model se nadovezuje na istraživanju Yoo, Donthu i Lee (2000) koji tretiraju percipiranu kvalitetu, lojalnost marki i poznatost marke kao varijable koje utječu na tržišnu vrijednost marke, s tim da je autorica dodala aktivnosti digitalnog marketinga kao dodatnu neovisnu varijablu koja utječe na tržišnu vrijednost marke te je odstranila varijablu lojalnost marke s modela jer se u ovoj studiji radi o relativno novom poduzeću, stoga je analiza lojalnosti neprimjenjiva u ovome slučaju.

U literaturi se pojavljuje dosta različitih modela, kao na primjer model predložen od strane Anića i Rajha (2008), koji ne analiziraju tržišnu vrijednost marke, nego lojalnost marki uzimaju kao zavisnu varijablu, a percipiranu kvalitetu i poznatost marke kao nezavisne varijable. Bilgin (2018) je razvio model koji uključuje tri varijable: marketing na društvenim mrežama, poznatost marke, lojalnost marki i imidž marke, i njegov je cilj bio istražiti učinak marketinških aktivnosti na društvenim mrežama na poznatost marke, imidž i lojalnost marki. Drugi je cilj mjerenje učinka poznatost marke na imidž marke. Treći je analizirati učinak poznatosti i imidža na lojalnost marke. 
Kao što je navedeno u pregledu literature, veliki je broj studija utvrdilo snažnu povezanost i uzročni učinak poznatosti marke, lojalnost marki, aktivnosti digitalnog marketinga te percepciju kvalitete na tržišnu vrijednost marke. Istraživanja na tu temu su u industriji antikviteta, starina i stilskog namještaja oskudne, kako u zapadnim ekonomijama, tako i u zemljama u razvoju.

Nepoznavanje robne marke dovodi do smanjenja tržišne vrijednosti marke. Dakle, svijest o marki prethodi drugim dimenzijama tržišne vrijednosti marke (Civelek \& Ertemel, 2019). Stoga, u svjetlu postojeće literature, pretpostavljamo da:

H1: Poznatost marke ima značajan i pozitivan utjecaj na tržišnu vrijednost marke.

Aaker (1991) navodi da je percipirana kvaliteta subjektivna procjena potrošača o ukupnoj izvrsnosti ili superiornosti proizvoda. Kada uzmemo u obzir značaj kvalitete za marku, pretpostavljamo da pozitivna i snažna percepcija kvalitete će ojačati vrijednost tržišne marke:

H2: Percepcija kvalitete ima značajan i pozitivan utjecaj na tržišnu vrijednost marke.

Studija Godey et al. (2016) otkriva da aktivnosti digitalnog marketinga imaju značajan pozitivan učinak na tržišnu vrijednost marke i to na dvije glavne dimenzije robne marke: poznatost marke i imidž marke. Dumitriu et al. (2019) navode da aktivnosti digitalnog marketinga trebaju predstavljati inspiraciju za mala i srednja poduzeća u stvaranju dugoročne tržišne vrijednosti za marku. Stoga, pretpostavljamo da:

H3: Aktivnosti digitalnog marketinga imaju značajan i pozitivan utjecaj na tržišsnu vrijednost marke.

Slika 1. Teorijski okvir

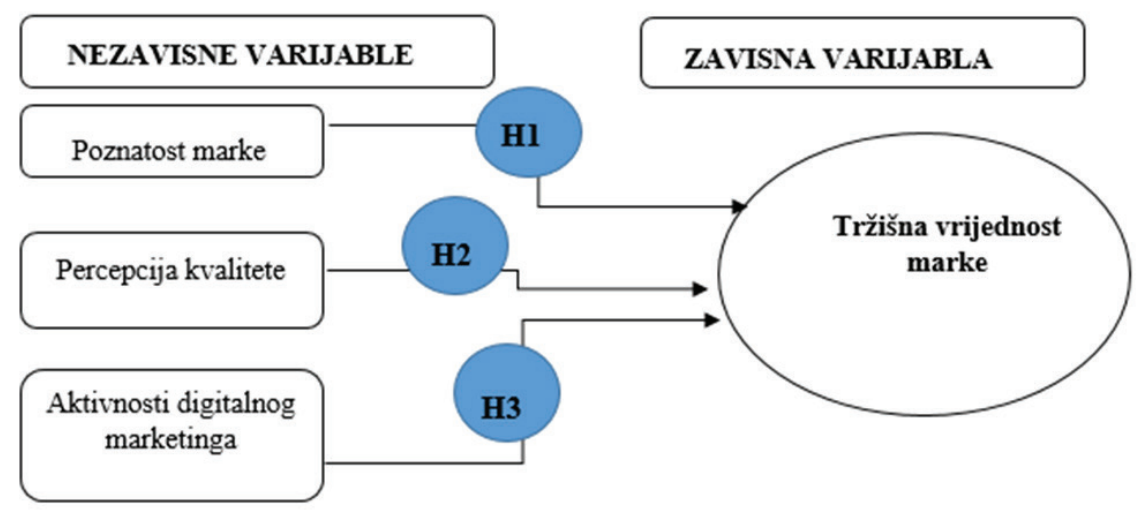

Izvor: Izrada autora 
Studija se temelji na prikupljenim primarnim i sekundarnim podacima putem strukturiranog upitnika koji je dizajniran tako da bude kratak i ne previše nametljiv, kako bi se postigao veći broj povratnih informacija i povratnih odgovora kupaca. Kao mjerni instrument za potrebe istraživanja kreiran je anketni upitnik koji se sastoji od dva dijela. Prvi dio pitanja (prvih šest pitanja) odnosi se na socioekonomske i demografske varijable (pitanja koja se usredotočuju na dob, spol, razinu obrazovanja i godišnje prihode), dok drugi dio (28 pitanja za četiri varijable - sedam pitanja za svaku varijablu) sadrži niz izjava tako da će ispitaniku biti lako dati razinu slaganja s danim izjavama prema Likertovoj skali od pet stupnjeva. Skala se sastoji od tvrdnji „,uopće se ne slažem”, „ne slažem se”, „nemam mišljenje”, ,slažem se” i ,potpuno se slažem”. Kompletan upitnik nalazi se u dodatku rada. Ovih 28 pitanja izabrano je savjetovanjem i uz pomoć modela s raznih relevantnih studija, poput Rajh (2005), Anić \& Rajh (2008), Yoo, Donthu $\&$ Lee (2000), Aslam et al. (2018) te Lee \& Leh (2011). Upitnik je distribuiran u razdoblju od siječnja 2020. do lipnja 2020.

Analizirano poduzeće posluje od lipnja 2017. godine i ima sjedište u Koprivnici (Republika Hrvatska). Registrirano je za trgovinu na malo preko interneta ili pošte te se bavi trgovinom antikviteta, starina, stilskog namještaja i dekoracija. Početni uzorak obuhvatio je 135 potencijalnih i postojećih kupaca kojima je bio ponuđeno sudjelovanje u istraživanju putem fizičkog popunjavanja ankete ili online poveznicu, od kojih je 100 upitnika bila kompletno i pravilno ispunjeno te uzeto za daljnju analizu. 
Tablica br. 1. Demografski podaci primjerka

\begin{tabular}{|c|c|c|c|c|}
\hline & Varijabli & Klasifikacija & Frekvencija & Udio \\
\hline \multirow{3}{*}{1} & \multirow{3}{*}{ Spol } & muški & 56 & $56 \%$ \\
\hline & & ženski & 44 & $44 \%$ \\
\hline & & Ukupno & 100 & $100 \%$ \\
\hline \multirow{6}{*}{2} & \multirow{6}{*}{ Starost } & $18-39$ & 7 & $7 \%$ \\
\hline & & $40-49$ & 17 & $17 \%$ \\
\hline & & $50-59$ & 5 & $5 \%$ \\
\hline & & $60-69$ & 48 & $48 \%$ \\
\hline & & $70-99$ & 23 & $23 \%$ \\
\hline & & Ukupno & 100 & $100 \%$ \\
\hline \multirow{5}{*}{3} & \multirow{5}{*}{ Bračni status } & samac & 39 & $39 \%$ \\
\hline & & u braku & 49 & $49 \%$ \\
\hline & & rastavljen & 10 & $10 \%$ \\
\hline & & udovac/-ica & 2 & $2 \%$ \\
\hline & & Ukupno & 100 & $100 \%$ \\
\hline \multirow{5}{*}{4} & \multirow{5}{*}{ Obrazovne kvalifikacije } & SSS & 24 & $24 \%$ \\
\hline & & VSS & 47 & $47 \%$ \\
\hline & & mr.sc. & 15 & $15 \%$ \\
\hline & & dr.sc. & 14 & $14 \%$ \\
\hline & & Ukupno & 100 & $100 \%$ \\
\hline \multirow{5}{*}{5} & \multirow{6}{*}{$\begin{array}{l}\text { Mjesečni prihodi } \\
\text { (u HRK) }\end{array}$} & Ispod 5.000 & 14 & $14 \%$ \\
\hline & & $5.000-6.750$ & 30 & $30 \%$ \\
\hline & & $6.750-15.000$ & 18 & $18 \%$ \\
\hline & & $15.000-37.500$ & 22 & $22 \%$ \\
\hline & & Iznad 37.500 & 16 & $16 \%$ \\
\hline \multirow{9}{*}{6} & & Ukupno & 100 & $100 \%$ \\
\hline & \multirow{8}{*}{ Zanimanje } & poduzetnik & 32 & $32 \%$ \\
\hline & & med. doktor & 20 & $20 \%$ \\
\hline & & sveučilišni profesor & 7 & $7 \%$ \\
\hline & & odvjetnik & 4 & $4 \%$ \\
\hline & & dizajner & 7 & $7 \%$ \\
\hline & & zaposlen & 25 & $25 \%$ \\
\hline & & nezaposlen & 5 & $5 \%$ \\
\hline & & Ukupno & 100 & $100 \%$ \\
\hline
\end{tabular}

Izvor: Izrada autora 
Demografski podaci prikazuju da je $56 \%$ uzoraka sastavljeno od ispitanika muškog te $44 \%$ ispitanica ženskog spola, $48 \%$ ispitanika imaju od 60-69 godina, te je $49 \%$ njih u braku, a $38 \%$ ispitanika zarađuje više od 15.000 kuna mjesečno. Što se tiče obrazovanja, čak $76 \%$ ispitanika izjavilo je da ima minimalno visokoškolsko obrazovanje, a njih 95 \% izjavilo je da je zaposleno.

\section{REZULTATI I RASPRAVA}

Prikupljeni empirijski podaci analizirani su većim brojem različitih statističkih metoda. Analiza je započela testom pouzdanosti te analizom korelacije (validnosti) i završila višestrukom regresijskom analizom, sve obavljeno uz pomoć IBM-ovog softwarea SPSS.

\subsection{Test pouzdanosti (Reliability test)}

$\mathrm{Na}$ početku, provedeno je testiranje pouzdanosti korištenjem Cronbach-ovog koeficijenta alfa, koji pomaže utvrditi ljestvicu pouzdanosti na temelju interne (unutarnje) konzistentnosti pouzdanosti izlučenih čimbenika (varijabla), tj. za procjenu dosljednosti ispitanikovih odgovora na pitanja. Najčešće se koristi kada se u anketi / upitniku pojavljuje više Likertovih pitanja koja čine ljestvicu i potrebno je utvrditi je li mjerna ljestvica pouzdana. Test pouzdanosti sproveden je za 28 stavki (izjava) iz upitnika. Što je vrijednost Cronbach-ove alphe veća, to je jači odnos između nezavisnih i zavisnih varijabli. Uz to, varijabla udovoljava zahtjevu pouzdanosti ako je vrijednost alpha jednaka ili veća od 0,6 . Svaka vrijednost alpha koja padne ispod 0,6 smatra se nepouzdanim rezultatom, dok se za vrijednost alfa koja postiže 0,9 i više smatra izvrsnim i najboljim rezultatom u njihovoj unutarnjoj dosljednosti (Chaia, Tanb \& Goh, 2016). Ako je alfa previsoka, to može sugerirati da su neke stavke (pitanja u anketi) suvišne jer testiraju isto stajalište ili mišljenje, ali u drugom ruhu (Glen, 2020). U ovom istraživanju Cronbach-ova alpha iznosi 0.877 , što je prihvatljiva pouzdanost testa. Visoka vrijednost Cronbach-ove alphe pokazatelj je vrlo visokog stupnja pouzdanosti ljestvice, i to također pokazuje da su stavke u visokoj korelaciji (Choudhurya, Singhb \& Saikiac, 2016).

Tablica 2. Cronbach-ova alpha

\begin{tabular}{|c|c|c|}
\hline \multicolumn{3}{|c|}{ Test pouzdanosti } \\
\hline $\begin{array}{c}\text { Cronbachova alpha } \\
0,877\end{array}$ & $\begin{array}{c}\text { Cronbachova alpha bazirana } \\
\text { na standardizirane varijable } \\
0,876\end{array}$ & $\begin{array}{c}\mathrm{N} \text { (Broj varijabla) } \\
28\end{array}$ \\
\hline
\end{tabular}

Izvor: SPSS rezultat istraživanja 
Ono što se da zaključiti iz deskriptivne statistike varijabla (tablica broj 3) jest da su srednje vrijednosti za poznatost marke 3.54 , za percepciju kvalitete 3.51 , za aktivnosti digitalnog marketinga 3.63 te za tržišnu vrijednost marke 3.80, odnosno da se najveći broj ispitanika složio s izjavama iz upitnika kod pitanja za tržišnu vrijednost marke te aktivnosti digitalnog marketinga. Rezultati upućuju na to da se dodatno treba raditi na poznatosti marke te percepciju kvalitete te se oni mogu protumačiti činjenicom da analizirano poduzeće najviše ulaže u online vidljivost kod poznatosti marke, što većini ispitanika nije primaran medij (iznad $48 \%$ ispitanika je između 60 i 69 godina starosti). Što se tiče percepcije kvalitete, rezultati se mogu protumačiti imajući u vidu da se ovdje radi o trgovini starinama, tj. starim i rabljenim predmetima. Stoga je kupcima jasno da se antikviteti i starine prodaju u stanju „takvo kakvo jest“ (as is), pa im je percepcija kvalitete različita nego u slučajima bilo koje druge industrije ili proizvoda. Dobiveni rezultati su izuzetno zanimljivi s obzirom na činjenicu da se radi o prvom empirijskom istraživanju u industriji antikviteta, starina i luksuznih dobara. Također rezultati bacaju novu svijetlo na važnosti aktivnosti digitalnog marketinga za tržišnu vrijednost marke. Dosadašnje studije pokazuju da su aktivnosti digitalnog marketinga važne (Sasmita \& Mohd Suki, 2015), a ova studija to dodatno potvrđuje i za industriju antikviteta, starina i stilskog namještaja u Republici Hrvatskoj.

Tablica 3. Deskriptivna statistika

\begin{tabular}{|lccc|}
\hline \multicolumn{4}{c|}{ Deskriptivna statistika } \\
POZNATOST MARKE & Mean & Std. Deviation & $\mathrm{N}$ \\
PERCEPCIJA KVALITETE & 3,545 & 0,561 & 100 \\
AKTIVNOSTI DIGITALNOG & 3,511 & 0,526 & 100 \\
$\begin{array}{l}\text { MARKETINGA } \\
\text { TRŽIŠNA VRIJEDNOST }\end{array}$ & 3,634 & 0,504 & 100 \\
MARKE & 3,800 & 0,470 & 100 \\
\hline
\end{tabular}

Izvor: SPSS rezultat istraživanja

\subsection{Analiza korelacije (Test validnosti)}

Ukupne karakteristike varijabla i snaga odnosa među glavnim varijablama istražuju se pomoću Pearson-ove korelacijske analize. Rezultati su pokazali da su varijable korelirane jer je između svih varijabla pronađen pozitivan koeficijent korelacije koji prelazi razinu značajnosti (tablica broj 4). 
Tablica br. 4. Korelacijska analiza između varijabla

\section{Correlations}

\begin{tabular}{|c|c|c|c|c|c|}
\hline & & $\begin{array}{l}\text { POZNATOST } \\
\text { MARKE }\end{array}$ & $\begin{array}{l}\text { PERCEPCIJU } \\
\text { KVALITETE }\end{array}$ & $\begin{array}{l}\text { AKTIVNOSTI } \\
\text { DIGITALNOG } \\
\text { MARKETINGA }\end{array}$ & $\begin{array}{c}\text { TRŽIŠNA } \\
\text { VRIJEDNOST } \\
\text { MARKE }\end{array}$ \\
\hline \multirow[t]{5}{*}{ POZNATOST MARKE } & Pearson Correlation & 1 & $.828^{n \pi}$ & $816^{n \pi}$ & $.787^{\kappa \times}$ \\
\hline & Sig. (2-tailed) & &, 000 &, 000 &, 000 \\
\hline & $\begin{array}{l}\text { Sum of Squares and } \\
\text { Cross-products }\end{array}$ & 31,158 & 24,213 & 22,835 & 20,588 \\
\hline & Covariance &, 315 &, 245 &, 231 & ,208 \\
\hline & $\mathrm{N}$ & 100 & 100 & 100 & 100 \\
\hline \multirow{5}{*}{$\begin{array}{l}\text { PERCEPCIJU } \\
\text { KVALITETE }\end{array}$} & Pearson Correlation & $828^{\prime \prime}$ & 1 & $881^{n \times}$ &, $797^{\star \star}$ \\
\hline & Sig. (2-tailed) &, 000 & &, 000 &, 000 \\
\hline & $\begin{array}{l}\text { Sum of Squares and } \\
\text { Cross-products }\end{array}$ & 24,213 & 27,436 & 23,132 & 19,555 \\
\hline & Covariance &, 245 & 277 &, 234 & , 198 \\
\hline & $\mathrm{N}$ & 100 & 100 & 100 & 100 \\
\hline \multirow{5}{*}{$\begin{array}{l}\text { AKTIVNOSTI } \\
\text { DIGITALNOG } \\
\text { MARKETINGA }\end{array}$} & Pearson Correlation &, $816^{\mathrm{n}}$ &, $881^{\star *}$ & 1 &, $845^{\mathrm{N}}$ \\
\hline & Sig. (2-tailed) &, 000 &, 000 & &, 000 \\
\hline & $\begin{array}{l}\text { Sum of Squares and } \\
\text { Cross-products }\end{array}$ & 22,835 & 23,132 & 25,156 & 19,849 \\
\hline & Covariance &, 231 &, 234 &, 254 &, 200 \\
\hline & $\mathrm{N}$ & 100 & 100 & 100 & 100 \\
\hline \multirow{5}{*}{$\begin{array}{l}\text { TRŽIŠNA VRIJEDNOST } \\
\text { MARKE }\end{array}$} & Pearson Correlation &, $787^{\star *}$ &, $797^{\star \star}$ & $845^{* *}$ & 1 \\
\hline & Sig. (2-tailed) &, 000 &, 000 &, 000 & \\
\hline & $\begin{array}{l}\text { Sum of Squares and } \\
\text { Cross-products }\end{array}$ & 20,588 & 19,555 & 19,849 & 21,959 \\
\hline & Covariance & ,208 & ,198 & 200 &, 222 \\
\hline & $\mathrm{N}$ & 100 & 100 & 100 & 100 \\
\hline
\end{tabular}

**. Correlation is significant at the 0.01 level (2-tailed).

Izvor: SPSS rezultat istraživanja

\subsection{Regresijska analiza}

Utjecaj triju čimbenika (poznatost marke, percepcija kvalitete te aktivnosti digitalnog marketinga) na tržišnu vrijednost marke testira se uporabom modela višestruke regresije.

Ovaj je model predstavljen sljedećom jednadžbom:

$$
\mathrm{Y}=\mathrm{a}+\mathrm{b} 1 \mathrm{X} 1+\mathrm{b} 2 \mathrm{X} 2+\mathrm{b} 3 \mathrm{X} 3+\mathrm{E}
$$

gdje je $\mathrm{Y}=$ tržišna vrijednost marke, $\mathrm{a}=$ slobodan član, $\mathrm{X} 1=$ poznatost marke, $\mathrm{X} 2=$ percepcija kvalitete, $\mathrm{X} 3$ = aktivnosti digitalnog marketinga i $\mathrm{E}=$ latentna varijabla (slučajna pogreška). 
Tablica br. 5. Analiza nestandardnih i nestandardiziranih koeficijenata

\begin{tabular}{|c|c|c|c|c|c|}
\hline \multicolumn{6}{|c|}{ Koeficijenti } \\
\hline \multirow{2}{*}{$\begin{array}{l}\text { Model } \\
\text { B }\end{array}$} & \multicolumn{2}{|c|}{$\begin{array}{l}\text { Nestandardizirani } \\
\text { koeficijenti }\end{array}$} & \multirow[t]{2}{*}{$\begin{array}{l}\text { Standardizirani } \\
\text { koeficijenti }\end{array}$} & \multirow{3}{*}{$\begin{array}{c}\mathrm{t} \\
4,841\end{array}$} & \multirow{3}{*}{$\begin{array}{l}\text { Sig. } \\
0,000\end{array}$} \\
\hline & Std. Error & Beta & & & \\
\hline (Constant) & 0,862 & 0,178 & & & \\
\hline $\begin{array}{l}\text { POZNATOST } \\
\text { MARKE }\end{array}$ & 0,216 & 0,082 & 0,257 & 2,642 & 0,010 \\
\hline $\begin{array}{l}\text { PERCEPCIJA } \\
\text { KVALITETE }\end{array}$ & 0,099 & 0,106 & 0,110 & 0,928 & 0,355 \\
\hline $\begin{array}{c}\text { AKTIVNOSTI } \\
\text { DIGITALNOG } \\
\text { MARKETINGA }\end{array}$ & 0,502 & 0,108 & 0,538 & 4,669 & 0,000 \\
\hline
\end{tabular}

Izvor: SPSS rezultat istraživanja

Sukladno rezultatima u tablici 5, jednadžba modela iz ove studije jest:

$\mathrm{Y}=0,862+0,216 \mathrm{X} 1+0,099 \mathrm{X} 2+0,502 \mathrm{X} 3$

Pretpostavljajući da su svi drugi čimbenici konstantni, jednadžba ukazuje na to da će jedinica povećanje poznatosti marke, percepcija kvalitete i aktivnosti digitalnog marketinga povećati tržišnu vrijednost marke za $0.216,0,099$ i 0.502 respektivno. Zapravo rezultati prikazuju da napori i aktivnosti digitalnog marketinga imaju najveći utjecaj na tržišnu vrijednost marke.

Tablica br. 6. Zaključak modela

\begin{tabular}{|c|c|c|c|c|}
\hline \multicolumn{4}{|c|}{ Zaključak modela } \\
\hline Model & $\mathrm{R}$ & R Square & $\begin{array}{c}\text { Adjusted R } \\
\text { Square }\end{array}$ & Std. Error of the Estimate \\
\hline 1 &, $863 \mathrm{a}$ & 0,744 & 0,736 & 760046438,000000000000000 \\
\hline \multicolumn{4}{|c|}{ a. Nezavisne varijable: (Constant), AKTIVNOSTI DIGITALNOG MARKETINGA, } \\
POZNATOST MARKE, PERCEPCIJU KVALITETE \\
\hline \multicolumn{4}{|c|}{ b. Zavisna varijabla: TRŽIŠNA VRIJEDNOST MARKE } \\
\hline
\end{tabular}

Izvor: SPSS rezultat istraživanja 
Rezultati višestruke regresije (tablica broj 6) prikazuju koliko je jaka međuzavisnost zavisnih varijabla s nezavisnom varijablom preko indeksa korelacije $\mathrm{R}$. Indeks determinacije R2 pokazuje koliki je postotak varijabiliteta zavisne varijable objašnjen varijabilitetom nezavisnih varijabli. U primjeru iz tablice 6 , indeks determinacije $R$ Square je $74,4 \%$, što je dosta blizu poželjnog rezultata od $70 \%$, što upućuje na to da nezavisne varijable zajedno mogu objasniti oko $74 \%$ zavisnu varijablu (tržišnu vrijednost marke).

Autorica je izvršila korelacijsku i višestruku regresijsku analizu, gdje je tržišna vrijednost marke navedena kao zavisna varijabla, dok su poznatosti marke, percepcije kvalitete te aktivnosti digitalnog marketinga nezavisne varijable u svrhu ispitivanja hipoteza. Nakon provedenih statističkih testova i analiza korelacije i regresije između svih varijabla u modelu, rezultati upućuju na to da:

H1: Poznatost marke ima značajan i pozitivan utjecaj na tržišnu vrijednost marke.

Odnos između poznatosti marke i tržišne vrijednosti marke pozitivan je i značajan s vrijednošću od 0.787 . Stoga se hipoteza H1 prihvaća te ovaj rezultat jasno ukazuje na to da poznatost marke pozitivno i značajno utječe na tržišnu vrijednost marke.

H2: Percepcija kvalitete ima značajan i pozitivan utjecaj na tržišnu vrijednost marke.

Kod percepcije kvalitete, hipoteza H2 se odbacuje jer rezultat pokazuje da je odnos statistički neznačajan (Sig $=0,355)$, što se može protumačiti da u ovoj industriji te u ovom analiziranom uzorku percepcija kvalitete ne utječe značajno na tržišnu vrijednost marke. Pri analizi ovih rezultata treba imati u vidu da je ovo istraživanje industrije antikviteta, starina i stilskog namještaja, gdje percepcija kvalitete ima sekundarno značenje zbog prirode same industrije, odnosno predmet trgovine je rabljena i stara roba.

H3: Aktivnosti digitalnog marketinga imaju značajan i pozitivan utjecaj na tržišnu vrijednost marke.

Kao što su mnogi istraživači već dokazali, i ovim se istraživanjem dokazuje da aktivnosti digitalnog marketinga (prisustvo na društvenim mrežama, blog posto$v i$, digitalizacija poslovanja te online vidljivost) pozitivno i značajno utječu na tržišnu vrijednost marke. Hipoteza H3 se ovim modelom i studijom prihvaća.

Rezultati ovog istraživanja pomogli bi marketinškim stručnjacima, menadžerima i malim poduzetnicima u formuliranju strategija za poboljšanje vrijednosti njihove marke kako bi se postigla konkurentska prednost i održivost poslovanja. 


\subsection{Nedostaci i ograničenja studije}

Ova je studija iznova istražila poznati fenomen, tržišnu marku, kojoj se posvećuje stalna pozornost od strane akademskih istraživača, menadžera i medija.

Ipak, provedeno istraživanje i analiza imaju i određenih nedostataka i ograničenja. Ono je, kao i većina drugih marketinških istraživanja, provedeno u određenom trenutku te bi ponovljeno kontinuirano ispitivanje, tijekom duljeg vremenskog razdoblja, doprinijelo većoj pouzdanosti rezultata (Soče Kraljević et al., 2016). Također, istraživanje je provedeno na području Republike Hrvatske, tj. na relativno malom uzorku nasumično izvučeno iz baze postojećih i potencijalnih kupaca analiziranog poduzeća iz Koprivnice, a time rezultati istraživanja ne moraju vrijediti za sva poduzeća koje posluju u industriji antikviteta i stilskog namještaja u zemlji ili inozemstvu. Rezultati ne mogu niti predstavljati cijelu populaciju Hrvatske. Bilo bi zanimljivo ove rezultate usporediti s razvijenijim i manje razvijenim zemljama u regiji. Sama veličina uzorka je također ograničenje ove studije te bi u drugim budućim istraživanjima bilo zanimljivo ispitati veći broj ispitanika. U budućim istraživanjima, potrebno je uključiti i varijablu lojalnost marki (kao kod Yoo, Donthu i Lee, 2000), dok će analizirano poduzeće imati solidnu bazu postojećih lojalnih kupaca. Potrebna su daljnja kvantitativna istraživanja u različitim zemljama i različitim industrijama kako bi se identificirale dimenzije tržišne vrijednosti marke, te kako bi se moglo predvidjeti ponašanje potrošača u različitim kontekstima. Buduća se istraživanja trebaju također fokusirati na utjecaj različitih pojedinih aktivnosti digitalnog marketinga na tržišnu vrijednost marke.

S obzirom na nedostatak studija o tržišnoj vrijednosti marke u industrijama luksuznih dobara (a još manje u industriji antikviteta i umjetnina), ova bi studija trebala dati dragocjene informacije za trgovačka ili poduzeća koja plasiraju svoje proizvode i izrađuju marketinške strategije u izazovnom 21. stoljeću.

\section{ZAKLJUČAK}

Sve više poduzeća u Hrvatskoj shvaća da se mora prilagoditi svojim kupcima te novim izazovima u poslovanju (digitalizacija, globalizacija te nove informacijske i komunikacijske tehnologije). Analizirano poduzeće sa sjedištem u Koprivnici dobar je primjer kako i nekonvencionalne industrije mogu digitalizirati svoje poslovanje, koristiti mnogobrojne prednosti digitalnog marketinga te pozicionirati svoje poduzeće tako da postojeći i potencijalni kupci poznaju i svjesni su postojanja marke, prepoznaju ime i logo poduzeća te ga preferiraju ispred konkurencije. 
Rezultati ovog istraživanja pokazali su da poznatost marke i aktivnost digitalnog marketinga značajno i pozitivno utječu na tržišnu vrijednost marke, a da percepcija kvalitete ne utječe na tržišnu vrijednost marke (što znači da je moguće da su korelirane, ali da je to nelinearna veza). Zanimljivo je to što percepcija kvalitete u ovoj industriji ne utječe značajno na tržišnu vrijednost marke, što se može dodatno pojasniti činjenicom da se analizirana koprivnička tvrtka bavi trgovinom rabljenim (starim, antiknim) namještajem i antikvitetima, pa je potrošačima jasno da percepcija kvalitete u ovoj studiji ne utječe na tržišnu vrijednost marke.

Ovaj rad predstavlja osnovu za buduća istraživanja u ovom području te je prvi rad koji obuhvaća i analizira industriju antikviteta, umjetnina i starina u Hrvatskoj i općenito u regiji.

\section{LITERATURA}

1. Aaker, A.D., (1991), Managing Brand Equity: Capitalizing on the Value of a Brand Name. The Free Press, New York, USA

2. Aaker, A.D., (1996), Measuring Brand Equity Across Products and Markets, California Management Review, Vol. 38 (3), pp. 102-120

3. AbdGhani, N.H., Nawi, N.C., Rahman , A.A.A., (2021), Sources of brand equity: An investigation in SMEs context, AIP Conference Proceedings 2347, https://doi.org/10.1063/5.0053477

4. Alpeza, M., Oberman, M., Has, M., (2018), Small and Medium Enterprises Report-Croatia 2019 including the results of GEM - Global Entrepreneurship Monitor research for Croatia for 2018, CEPOR

5. Anić, I., Rajh, E., (2008), Strukturni model utjecaja intenziteta distribucije na percipiranu kvalitetu, poznatost marke i na lojalnost marki, Tržište- Market, Vol. XX, br. 2, pp. 133 - 147

6. Art and antiques trade (1998), Cultural Trends, 8:29, 37-65, DOI: 10.1080/09548969809365028

7. Asif, M., Abbas, K., Kashif, M., Hussain, S., Hussain, I., (2015), Impact of Brand Awareness and Loyalty on Brand Equity, Journal of Marketing and Consumer Research, vol. 12, pp 67-71

8. Aslam, W., Ham, M., Farhat, K., (2018), Influencing factors of brand perception on consumers' repurchase intention: An examination of online apparel shopping, Management, 23(2), str. 87-102. https://doi.org/10.30924/ mjcmi/2018.23.2.87

9. Azad, N., Safaei, M., (2012), The impact of brand value on brand selection: Case study of mobile phone selection, Management Science Letters 2, pp. $1233-1238$ 
10. Balakrishnan, B., Lee, S., Azlinda Shazneem Md.Shuaib, A.S., Marmaya, N.H., (2009), The impact of brand personality on brand preference and loyalty: empirical evidence from Malaysia, Business education \& accreditation Volume 1 Number 1

11. Bilgin, Y., (2018), The Effect Of Social Media Marketing Activities On Brand Awareness, Brand Image And Brand Loyalty, BMIJ, 6(1): 128-148 doi: 10.15295/BMIJ.V6I1.229

12. Brogi, S., Calabrese, A., Campisi, D., Capece, G., Costa, R., Di Pillo, F., (2013), The Effects of Online Brand Communities on Brand Equity in the Luxury Fashion Industry, International Journal of Engineering Business Management, 5, 1-9. 10.5772/56854.

13. Buil, I., de Chernatony, L., Martínez, E., (2008), A cross-national validation of the consumer-based brand equity scale, Journal of Product \& Brand Management, Vol. 17 No. 6, pp. 384-392. https://doi. org/10.1108/10610420810904121

14. Cakmak, I., (2016), The role of brand awareness on brand image, perceived quality and effect on risk in create brand trust, Global Journal on Humanities and Social Sciences. 10.18844/gjhss.v0i0.441.

15. Chaia, B.B., Tanb, P.S., Goh, T.S., (2016), Banking Services that Influence the Bank Performance, Procedia - Social and Behavioral Sciences 224, pp. $401-407$

16. Choudhurya, M., Singhb, R., Saikiac, H., (2016), Measuring customer experience in Bancassurance: an empirical study, Market-Tržište, Vol. 28, No. 1, 2016, pp. 47-62

17. Civelek, M. E., Ertemel, A. V., (2019), The role of brand equity and perceived value for stimulating purchase intention in b2c ecommerce web sites, Business and Economics Research Journal, 10(1), 233-243.

18. Crossman, A., (2020), Razumijevanje svrhovitog uzorkovanja. https:// hr.eferrit.com/razumijevanje-svrhovitog-uzorkovanja/, Accessed on 21.10.2020

19. Dumitriu, D., Militaru, G., Deselnicu, D.C., Niculescu, A., Popescu, M.A., (2019), A Perspective Over Modern SMEs: Managing Brand Equity, Growth and Sustainability Through Digital Marketing Tools and Techniques, Sustainability, 11, 2111; doi:10.3390/su11072111

20. Eid, R., El-Kassrawy, Y., (2012), The Effect of the Internet Use on Customer Relations and Targeting Activities: An Empirical Study of UK Companies, International Journal of Online Marketing (IJOM), IGI Global, vol. 2(3), pages 39-51

21. Fotova Čiković, K., (2020) Customer profiles in the antiques and collectibles industry in Croatia using gaussian mixture model clustering: An empirical 
study, Economic and Social Development (Book of Proceedings), „53rd International Scientific Conference on Economic and Social Development Development", Sveti Martin na Muri, Croatia, pp. 148-156

22. Glen, S., (2020), Cronbach's Alpha: Simple Definition, Use and Interpretation. From StatisticsHowTo.com: Elementary Statistics for the rest of us! https://www.statisticshowto.com/cronbachs-alpha-spss/, Accessed on: 30.10 .2020

23. Godey, B., Manthiou, A., Pederzoli, D., Rokka, J., Aiello,G., Donvito, R., Singh, R., (2016), Social media marketing efforts of luxury brands: Influence on brand equity and consumer behavior, Journal of Business Research, 69 (12), pp. 5833-5841, https://doi.org/10.1016/j.jbusres.2016.04.181.

24. Gorgani, M.R.N., (2016), The Impact of Social Network Media on Brand Equity in SMEs, European Journal of Sustainable Development, 5 (3), 239244, Doi: 10.14207/ejsd.2016.v 5n3p239

25. Grad Koprivnica (2020). www.koprivnica.hr, Accessed on: 05.11.2020

26. Harrigan, P., Ramsey, E., Ibbotson, P., (2011), Exploring and Explaining SME Marketing: Investigating e-CRM Using a Mixed Methods Approach, Journal of Strategic Marketing, 20(2), 127-163. https://doi.org/10.1080 /0965254X.2011.606911

27. Jalilvand, M.R., Samiei, N., Mahdavinia. S.H., (2011), The Effect of Brand Equity Components on Purchase Intention: An Application of Aaker's Model in the Automobile Industry, International Business and Management, Vol. 2, No. 2., pp. 149-158

28. Jung, J., Sung, E., (2008), Consumer-based brand equity: Comparisons among Americans and South Koreans in the USA and South Koreans in Korea, Journal of Fashion Marketing and Management, Vol. 12 No. 1, pp. 2435. https://doi.org/10.1108/13612020810857925

29. Keller, K.L., (1993), Conceptualizing, Measuring, and Managing $\mathrm{Cu}-$ stomer-Based Brand Equity, Journal of Marketing, 57(1), 1-22. doi: $10.2307 / 1252054$

30. Keller, K. L., (2003a), Brand synthesis: The multi-dimensionalities of brand knowledge, Journal of Consumer Research, 29, 595-600.

31. Keller, K. L., (2003b), Understanding brands, branding and brand equity, Interactive marketing, Vol. 5 no. 1 . pp 7-20. July/september 2003

32. Keller, K.L., (2013), Strategic Brand Management; Pearson Education Limited: London, UK

33. Kim, A.J., Ko, E., (2012), Do social media marketing activities enhance customer equity? An empirical study of luxury fashion brand, Journal of Business Research, 65. 1480-1486 
34. Kim, H-K, Lee, TJ., (2018), Brand Equity of a Tourist Destination, Sustainability, 10(2):431. https://doi.org/10.3390/su10020431

35. Krishnaprabha, S., Tarunika, R., (2020), An Analysis on Building Brand Awareness through Digital Marketing Initiatives, International Journal of Research in Engineering, Science and Management, vol. 3 issue 7, pp. 266-270

36. Lee, G.C., Leh, F.C.Y., (2011), Dimensions of Customer-Based Brand Equity: A Study on Malaysian Brands, Journal of Marketing Research and Case Studies, Vol. 2011, Article ID 821981 DOI: 10.5171/2011.821981

37. Mansour, I., (2015), The Impact of Marketing Efforts on Brand Equity: A Case of Samsung Brand in Sudan, Journal of Economic Sciences, 16, pp.113. 10.2139/ssrn.2613829.

38. Markić, B., Bijakšić, S., Bevanda, A., (2018), Komunikacija na društvenim mrežama i razvoj imidža o brendu turističke destinacije, HUM XIII, 19, pp. 233-248

39. Nam, J., Ekinci, Y., Whyatt, G., (2011), Brand equity, brand loyalty and consumer satisfaction, Annals of Tourism Research, Volume 38, Issue 3, 2011, Pages 1009-1030, ISSN 0160-7383, https://doi.org/10.1016/j. annals.2011.01.015.

40. Omar, M.W., Ali, M.N.M., (2010), Managing Brand Equity among Langkawi's (SMEs) Independent Hoteliers, International Journal of Marketing Studies, Vol. 2, No. 1

41. Primorac, D., (2020), Analiza poduzetničke inovativnosti na području sjeverne Hrvatske, Podravina, 19 (37), 80-88. Preuzeto s https://hrcak.srce. $\mathrm{hr} / 240010$

42. Rajh, E., (2005), Utjecaj elemenata marketinškog miksa na tržišnu vrijednost marke, Privredna kretanja i ekonomska politika, 15 (102), 30-59. Preuzeto s https://hrcak.srce.hr/18519

43. Rockute, K., Minelgaite, I., Zailskaite-Jakšte, L., Damaševicius, R., (2018), Brand Awareness in the Context of Mistrust: The Case Study of an Employment Agency. Sustainability, 10, 695; doi:10.3390/su10030695

44. Sasmita, J., Mohd Suki, N., (2015), Young consumers' insights on brand equity: Effects of brand association, brand loyalty, brand awareness, and brand image, International Journal of Retail \& Distribution Management, Vol. 43 No. 3, pp. 276-292. https://doi.org/10.1108/JJRDM-02-2014-0024

45. Sean Hyun, S, Kim, W., (2011), Dimensions of Brand Equity in the Chain Restaurant Industry, Cornell Hospitality Quarterly, 52(4), pp.429-437, doi:10.1177/1938965510397533

46. Seo, E., Park, J., (2018), A study on the effects of social media marketing activities on brand equity and customer response in the airline industry, 
Journal of Air Transport Management,Volume 66, pp.36-41,https://doi.org/10.1016/j.jairtraman.2017.09.014.

47. Soče Kraljević, S., Galić, S., Vidačak, Z., (2016), Istraživanje utjecaja demografskih čimbenika na impulzivnu kupnju, Zbornik radova Ekonomskog fakulteta Sveučilišta u Mostaru, (22), 26-48. Preuzeto s https://hrcak.srce. $\mathrm{hr} / 203898$

48. Širola, D., Gallopeni, V., (2020), The impact of brand equity on consumer behavior on Croatian mobile phone market, CroDiM, Vol. 3, No. 1, 2020

49. Tong, X., Hawley, J.M., (2009), Creating brand equity in the Chinese clothing market: The effect of selected marketing activities on brand equity dimensions, Journal of Fashion Marketing and Management, Vol. 13 No. 4, pp. 566-581. https://doi.org/10.1108/13612020910991411

50. Tritama, H.B., Tarigan, E.R., (2016), The Effect of Social Media to the Brand Awareness of a Product of a Company, CommIT Journal, vol. 10, no. 1, pp. 9-14

51. Valette-Florence, P., Guizani, H., Merunka, D., (2011), The impact of brand personality and sales promotions on brand equity, Journal of Business Research, Volume 64, Issue 1, Pages 24-28,ISSN 0148-2963, https://doi.or$\mathrm{g} / 10.1016 / \mathrm{j}$.jbusres.2009.09.015.

52. Veloutsou, C., Guzmán, F., (2017), The evolution of brand management thinking over the last 25 years as recorded in the Journal of Product and Brand Management, Journal of Product and Brand Management, 26(1), pp. 2-12. (doi:10.1108/JPBM-01-2017-1398)

53. Venkatalakshmi, K., (2015), A study on perception of brand identity among customers, International Journal of Management and Business Studies, vol. 5 , issue 1, pp. 62-64

54. Vranešević, T., Marušić, M., (2003), Mjerenje vrijednosti marke Zbornik Ekonomskog fakulteta u Zagrebu, godina 1, broj 1, 2003.

55. Yoo, B., Donthu, N., Lee, S., (2000), An Examination of Selected Marketing Mix Elements and Brand Equity, Journal of the Academy of Marketing Science, Vol. 28, No. 2, 2000, str.195-211

56. Yuvaraj, S., Indumatji, R., (2018), Influence of Digital Marketing on Brand Building, International Journal of Mechanical Engineering and Technology, vol. 9, issue 7, pp. 235-243

57. Zeithaml, V., (1988), Consumer Perceptions of Price, Quality and Value: A Means-End Model and Synthesis of Evidence, Journal of Marketing, No. 52, 2-22. 10.1177/002224298805200302. 


\section{Dodatak 1: Upitnik}

U kojoj se mjeri slažete ili ne slažete sa svakom od sljedećih izjava? Molimo zaokružite samo jedan odgovor za svaku tvrdnju na ljestvici od 1 do 5 .

1 - uopće se ne slažem, 2 - ne slažem se, 3 - nemam mišljenje, 4 - slažem se, 5 - potpuno se slažem.

\begin{tabular}{|c|c|c|}
\hline i1 & Ova marka mi je vrlo dobro poznata. & 12345 \\
\hline $\mathrm{i} 2$ & Preferiram brand Katema ispred svih drugih brandova. & 12345 \\
\hline $\mathrm{i} 3$ & Prepoznajem i razlikujem Katemin brand od konkurencije. & 12345 \\
\hline i4 & Nekih karakteristika branda Kateme se odmah sjetim. & 12345 \\
\hline i5 & $\begin{array}{l}\text { Dok se sjetim antikviteta, stilskog namještaja i rasvjete odmah se sjetim } \\
\text { i Kateme. }\end{array}$ & 12345 \\
\hline i6 & Lako prepoznajem Katemin logo i brand među konkurencijom. & 12345 \\
\hline i7 & Znam kako Katema izgleda. & 12345 \\
\hline i8 & Katema ima proizvode odlične kvalitete. & 12345 \\
\hline i9 & Katemini proizvodi imaju prihvatljiv stupanj kvalitete. & 12345 \\
\hline $\mathrm{i} 10$ & Katema je brand zbog kojeg bih se osjećao/la opušteno. & 12345 \\
\hline i11 & Katema je konzistentna u kvaliteti ponuđenih proizvoda. & 12345 \\
\hline i12 & Izdržljivost Kateminih proizvoda je velika. & 12345 \\
\hline i13 & Vjerojatnost da je Katemin proizvod u dobrom stanju je velika. & 12345 \\
\hline i14 & Katema je brand koji nudi drugačije proizvode od konkurencije. & 12345 \\
\hline i15 & Često naiđem na Katemine online sadržaje. & 12345 \\
\hline i16 & Katema kreira relevantan online sadržaj. & 12345 \\
\hline i17 & Blog postovi Kateme su uvijek zanimljivi i edukativni. & 12345 \\
\hline i18 & Redovito čitam newslettere dobivene od Kateme. & 12345 \\
\hline i19 & Katema se online reklamira sukladno vrijednostima marke. & 12345 \\
\hline $\mathrm{i} 20$ & Online vidljivost Kateme je izuzetno velika. & 12345 \\
\hline i 21 & Pratim Katemu na svim društvenim mrežama. & 12345 \\
\hline $\mathrm{i} 22$ & $\begin{array}{l}\text { Ako se druga marka ni na koji način ne razlikuje od Kateme, kupit ću } \\
\text { Katemin proizvod. }\end{array}$ & 12345 \\
\hline$i 23$ & $\begin{array}{l}\text { Ako bi postojala druga marka jednake kvalitete kao i Katema, radije bih } \\
\text { kupio/la Katemin proizvod. }\end{array}$ & 12345 \\
\hline $\mathrm{i} 24$ & $\begin{array}{l}\text { Smatram da je Katemin tim profesionalan i ima puno znanja u vezi anti- } \\
\text { kviteta i stilskog namještaja. }\end{array}$ & 12345 \\
\hline $\mathrm{i} 25$ & Katema nudi više benefita i pogodnosti nego drugi trgovci. & 12345 \\
\hline $\mathrm{i} 26$ & Preporučujem Katemu mojoj obitelji i prijateljima. & 12345 \\
\hline i 27 & $\mathrm{Ka}$ & 12345 \\
\hline $\mathrm{i} 28$ & Smatram da Katema ima unikatan brand imidž & 12345 \\
\hline
\end{tabular}


Katerina Fotova Čiković, PhD

University North, Koprivnica, Croatia

kcikovic@unin.hr

\title{
IMPACT OF BRAND AWARENESS, PERCEIVED QUALITY AND DIGITAL MARKETING EFFORTS ON BRAND EQUITY: EMPIRICAL STUDY OF THE CROATIAN COMPANY KATEMA
}

Received: January 7, 2021

Accepted: June 30, 2019

https://doi.org/10.46458/27121097.2021.27.25

\section{Preliminary communication}

\begin{abstract}
In today's competitive environment, branding is an important factor that differentiates similar products and services in the minds of consumers and makes them more desirable to consumers. A brand reflects the authenticity, value, and commitment to products and services (Bilgin, 2018). The market value of a brand is a key variable on which the company's success, growth and consumer perception depend.
\end{abstract}

The value of this paper is in the fact that the research of the brand equity in the industry of antiques, collectibles and antique furniture at the global level is insufficiently presented in the research and papers regarding this issue are rare. This empirical research aimed to determine the impact of brand awareness, perceived quality and digital marketing efforts on the brand equity, and to what extent and to further analyse brand perception in the antiques, collectibles and antique furniture industry in the case of a firm based in Koprivnica (Northern Croatia). Statistical tests, including reliability, validity test, correlation analysis, and regression analysis were used during this study.

The results of this research suggest that brand awareness and digital marketing efforts positively and significantly affect the brand equity, while the perceived quality is not statistically significant in explaining the dependent variable. 
The scientific contribution of this research is reflected in the fact that this paper can be used as a basis for further research in this poorly researched industry and the findings and the model can be applied to other industries, especially to increase the competitiveness of small and medium enterprises. The paper suggests that marketers should carefully consider the dimensions of brand equity when designing their brand strategies.

Keywords: brand awareness, brand equity, digital marketing, perceived quality

JEL: $M 31$ 